\title{
EFEKTIVITAS PENGELOLAAN NPL (NON PERFORMING LOAN) DI LEMBAGA PERKREDITAN DESA (LPD)
}

\author{
I Komang Dedy Saputra ${ }^{1}$ dan Ni Luh Eka Ayu Permoni ${ }^{2^{*}}$ \\ 1,2 Sekolah Tinggi Ilmu Ekonomi Satya Dharma Singaraja Bali \\ *Corresponding : ekapermoni87@gmail.com
}

\begin{tabular}{ll}
\hline CHRONICLE & \multicolumn{1}{c}{ ABSTRACT } \\
\hline & This study aims to analyze the effectiveness of the management of Non- \\
Article History: & Performing Loans (NPLs) in the Pedawa Traditional Village LPD through the \\
Received January 5, 2021 & Non Performing Loan (NPL) ratio, Capital Adequacy Ratio (CAR), Loan to \\
Accepted May 5, 2021 & Deposit Ratio (LDR), Earning Asset Quality (KAP) and Cost. Operational \\
& Operating Income (BOPO), the sample used in this study is financial reports for \\
Keywords : & 36months. The research was conducted using quantitative analysis methods. The \\
NPL, CAR, LDR, KAP, & results of this study explain that the Capital Adequacy Ratio (CAR) has a \\
BOPO & significant negative effect on Non-Performing Loans (NPL), and Loan to Deposit \\
& Ratio (LDR), Earning Asset Quality (KAP), and Operational Income \\
& Operational Costs (BOPO) have a significant effect. positive for Non Performing \\
& Loans (NPL).
\end{tabular}

\section{Latar Belakang :}

Berkembangnya perekonomian yang tumbuh cepat dalam era globalisasi dan usaha pemerintah untuk memperluas partisipasi aktif masyarakat di dunia usaha dalam bentuk pembangunan, menyebabkan peranan swasta yang bergerak di bidang jasa maupun dagang berkembang begitu pesat, sehingga dapat menyerap tenaga kerja dan dapat mengurangi pengangguran. Lembaga Perkreditan Desa (LPD) merupakan salah satu kebijakan pemerintah Daerah Bali di dalam upaya menyalurkan bantuan permodalan kepada masyarakat desa di Bali untuk meningkatkan perekonomian desa. Kegiatan utama dari LPD adalah menghimpun dana masyarakat berupa tabungan dan deposito, dan menyalurkan kembali kepada masyarakat yang membutuhkan dan dalam bentuk pinjaman atau kredit. Menurut peraturan Daerah Provinsi Bali Nomor 3 Tahun 2007, LPD merupakan badan usaha keuangan milik desa dan untuk krama desa. Dan menurut peraturan Daerah tingkat I Bali No.2 tahun 1998, LPD adalah suatu nama bagi usaha simpan pinjam milik masyarakat desa adat yang berada di Provinsi Daerah tingkat I Bali dan merupakan sarana perekonomian rakyat pedesaan. Dari pemaparan diatas dapat diambil kesimpulan bahwa LPD merupakan suatu perusahaan milik desa adat yang memiliki kegiatan menghimpun dana masyarakat dan menyalurkan kembali kepada yang membutuhkan modal untuk meningkatan perekonomian pedesaan.

Pendapatan terbesar LPD berasal dari penyaluran kredit, dan setiap kredit yang diberikan tidak lepas dari berbagai resiko yang dapat mengancam kesehatan LPD. Non Performing Loan (NPL) merupakan ukuran resiko kredit yang menjadi parameter tingkat kesehatan LPD. LPD dinilai memiliki potensi kesulitan yang membahayakan kelangsungan usahanya jika rasio kredit bermasalah (Non Performing Loan) secara neto lebih dari 5\% dari total kredit. Jika melebihi 5\% maka akan mempengaruhi penilaian tingkat kesehatan LPD tersebut. Semakin besar tingkat NPL maka Bank tersebut tidak profesional dalam pengelolaan kreditnya, sekaligus memberikan indikasi bahwa tingkat resiko atas pemberian kredit pada Bank tersebut cukup tinggi searah dengan tingginya NPL (Riyadi, 2006).

Dengan mengetahui rasio NPL suatu LPD, masyarakat dan pengelola LPD dapat mengambil langkah yang bijak dalam menyikapi dan menghadapi masalah tersebut. Peningkatan atau penurunan rasio NPL pada suatu LPD dapat dipengaruhi oleh berbagai faktor, baik internal, maupun eksternal 
LPD. Secara kuantitatif, faktor-faktor yang mempengaruhi NPL dapat berupa Capital Adequacy Ratio (CAR), Loan to Deposit Ratio (LDR), kualitas aktiva produktif (KAP), biaya operasional terhadap pendapatan operasional (BOPO). Selain itu, ada juga faktor lain yang menyebabkan terjadinya kredit bermasalah, seperti: proses analisis kredit yang buruk, produk gagal yang ditawarkan kepada nasabah, pinjaman berdasarkan kekuatan neraca bukan berdasarkan pinjaman arus kas, bank mengambil terlalu banyak kenyamanan dalam keamanan, asimetri informasi yang mengarah ke moral hazard, lingkungan ekonomi dan pengaruh politik (Chikoko et al., 2012; Hapsari, 2012). Secara makro ekonomi, penyebab utama tingginya tingkat NPL adalah perlambatan ekonomi, yang terlihat dari koefisien yang signifikan secara statistik dan ekonomi yang besar pada PDB, pengangguran dan tingkat inflasi (Skarica, 2014).

Capital Adequacy Ratio (CAR) adalah rasio yang memperlihatkan seberapa jauh seluruh aktiva bank yang mengandung resiko (kredit, penyertaan, surat berharga, tagihan pada bank lain) ikut di biayai dari dana modal sendiri bank disamping memperoleh dana-dana dari sumber-sumber di luar bank, seperti dana dari masyarakat, pinjaman dan lain-lain (Dendawijaya, 2003). Penurunan jumlah CAR merupakan akibat dari menurunnya jumlah modal suatu kelembagaan atau meningkatnya jumlah aktiva tertimbang menurut resiko (ATMR). CAR mempunyai pengaruh negatif terhadap NPL (Soebagio, 2005; Dianti \& Widyarti, 2012) dan Makri et al., (2014). Semakin tinggi CAR maka akan semakin kecil NPL. Penelitian Wardoyo dan Rusdiyanti (2009), Jusmansyah dan Sriyanto (2013) dan Vatansever dan Hepsen (2015), mengugkapkan bahwa CAR berpengaruh positif terhadap NPL. Maka semakin tinggi CAR akan semakin tinggi pula NPL.

Menurut Kasmir (2006), Loan to Deposit Ratio merupakan rasio untuk mengukur komposisi jumlah kredit yang diberikan dibandingkan dengan jumlah dana masyarakat dan modal sendiri yang digunakan. Penyaluran kredit merupakan kegiatan utama bank, oleh karena itu sumber pendapatan utama bank berasal dari kredit. Semakin besar kredit yang disalurkan dibandingkan dengan simpanan masyarakat pada suatu bank membawa konsekuensi bahwa semakin besar resiko yang harus ditanggung oleh bank yang bersangkutan (Dyanti \& Widyarti, 2012; Jayanti \& Haryanto, 2013; Akinlo \& Emmanuel, 2014).

KAP adalah penilaian terhadap faktor kualitas aktiva yang didasarkan pada perbandingan Aktiva produktif yang diklasifikasikan (APYD) terhadap aktiva produktifnya (Riyadi, 2004). Meningkatnya rasio KAP dipengaruhi oleh meningkatnya APYD atau menurunnya total biaya produktif. Jika APYD meningkat artinya kredit dalam perhatian kusus, kredit kurang lancar, kredit ditragukan, dan kredit macet juga meningkat. Dengan demikian, jika rasio KAP tinggi berati tingkat kredit macet atau bermasalah juga tinggi. Hal tersebut didukung penelitian yang dilakukan Soebagio (2005) dan Jayanti dan Haryanto (2013) bahwa KAP berpengaruh positif terhadap NPL.

BOPO adalah rasio perbandingan antara Biaya Operasional dengan Pendapatan Operasional (Riyadi, 2006). Rasio BOPO disebut sebagai rasio efisiensi yang digunakan untuk mengukur kemampuan manajemen bank dalam mengendalikan biaya operasional terhadap pendapatan operasional dalam kegiatan operasionalnya. Semakin kecil rasio BOPO berati semakin efesien biaya operasional yang dikeluarkan bank sehingga kemungkinan bank dalam kondisi bermasalah semakin kecil. Hal ini sejalan dengan penelitian yang dilakukan oleh Jayanti Dan Haryanto (2013) dan Hardoyo dan Rusdiyanti (2009) bahwa BOPO berpengaruh positif terhadap NPL.

Sebagai salah satu lembaga keuangan yaitu LPD Desa Adat Pedawa yang berolakasi di Desa Pedawa yang merupakan salah satu dari sekian banyak lembaga keuangan yang bergerak dalam bidang simpan pinjam. LPD Desa Adat Pedawa memiliki kegiatan yaitu menghimpun dana dari masyarakat dan menyalurkan kembali ke nasabah dalam bentuk pinjaman. Dalam pemberian pinjaman LPD memiliki tingkat resiko yang tinggi, karena setiap kredit yang diberikan bisa saja bermasalah. LPD Desa Adat Pedawa yang memiliki banyak pesaing harus selalu memperhatikan NPL yang ada untuk kelangsungan LPD kedepannya. 
Perkembangan pinjaman dari tahun 2017 sampai tahun 2019 yang dimiliki oleh LPD Desa Adat Pedawa. Jumlah Pinjaman yang direalisasikan mengalami penurunan pada tahun 2018 sebesar 13,40 \%, dan pada tahun 2019 mengalami peningkatan sebesar 40,26\%. Pinjaman lancar terus mengalami penurunan dari tahun 2017 sampai tahun 2019. Pinjaman kurang lancar mengalami penurunan pada tahun 2018 sebesar 74,15 \% dan mengalami peningkatan pada tahun 2019 sebesar $1.421 \%$. Pinjaman yang diragukan mengalami penurunan ditahun 2018 sebesar 78,34 \% dan mengalami peningkatan pada tahun 2019 sebesar $63,80 \%$. Dan untuk pinjaman macet mengalami peningkatan terbesar terjadi pada tahun 2018 sebesar 9.95\% dan pada tahun 2019 mengalami penurunan sebesar 0,08\%, dari tahun 2017 sampai 2019 pinajaman macet yang ada di LPD Desa Adat Pedawa melebihi batas maksimum 5\%.

\section{Tinjauan Pustaka}

\subsection{NPL (Non Performing Loan)}

Resiko kredit adalah merupakan resiko kerugian dimana bank tidak mendapatkan bunga dari kredit yang disalurkan kepada masyarakat, yang merupakan sumber keuntungan Bank. Bank yang terkena resiko kredit ditandai oleh kredit NPL (Non Performing Loan) (Sudirman, 2013). NPL merupakan rasio keuangan dipergunakan sebagai pengukuran rasio kredit. Ismail (2010) mengatakan bahwa NPL (Non Performing Loan) adalah rasio perbandingan antara jumlah kredit yang mengalami masalah pembayaran dengan total kredit yang diberikan oleh bank. Berdasarkan pengertian diatas dapat dinyatakan bahwa NPL adalah rasio perbandingan kredit bermasalah dengan jumlah kredit yang diberikan oleh bank. Bank Indonesia menetapkan nilai NPL maksimum adalah sebesar $5 \%$, apabila bank melebihi batas yang diberikan maka bank tersebut dikatakan tidak sehat. Menurut Sudirman (2013) dan Ismail (2010) rasio NPL dapat dihitung dengan rumus :

$$
\mathrm{NPL}=\frac{\text { Kredit bermasalah }}{\text { Total Kredit yang diberikan }} \times 100 \%
$$

Selain itu Standar Akuntansi keuangan No. 31 (Revisi 2000) juga merumuskan rasio NPL dengan rumus :

$$
\mathrm{NPL}=\underline{\text { Kredit kualitas kurang lancar, diragukan dan macet }} \text { X 100\% }
$$

\section{Total Kredit}

\subsection{Rasio capital adequacy ratio (CAR)}

Menurut Adisaputra (dalam, Ali 2004), untuk megurangi resiko yang terjadi dari masalah kredit, maka bank menyediakan dana untuk keperluan pengembangan usaha dan menampung risiko kerugian dana yang diakibatkan oleh kegiatan operasi bank yang disebut Capital Adequacy Ratio (CAR). Rasio capital adequacy ratio (CAR) memperlihatkan kecukupan modal yang dimiliki Lembaga untuk menunjang aktiva yang mengandung risiko, misalnya kredit yang diberikan (Dendawijaya, 2009). Rasio CAR diperoleh dari perbandingan antara modal yang dimiliki dengan Aktiva Tertimbang menurut Risiko (ATMR) (Riyadi, 2006).Berdasarkan pengertian diatas dapat diuraikan kembali bahwa CAR (Capital Adequacy Ratio) merupakan prosentase perbandingan antara modal LPD terhadap aktiva tertimbang menurut resiko (ATMR). Besarnya nilai rasio CAR dapat dihitung dengan rumus (Dendawijaya, 2009):

$$
(\mathrm{CAR})=\frac{\text { Modal LPD }}{\text { Aktiva Tertimbang Resiko (ATMR) }} \times 100 \%
$$

\subsection{Rasio loan to deposit ratio (LDR)}

LDR (loan to deposit ratio) digunakan untuk menilai likuiditas suatu bank dengan cara membagi jumlah kredit dengan jumlah dana yang dihimpun oleh bank, dengan kata lain seberapa jauh kemampuan bank dalam membayar kembali penarikan dana yang dilakukan oleh kreditur sebagai penyimpan dana dengan mengandalkan kredit yang diberikan sebagai sumber 
likuiditasnya (Dendawijaya 2005).

Menurut Kasmir (2006), Loan to Deposit Ratio merupakan rasio untuk mengukur komposisi jumlah kredit yang diberikan dibandingkan dengan jumlah dana masyarakat dan modal sendiri yang digunakan.

Menurut Riyadi (2006) LDR (loan to deposit ratio) adalah perbandingan antara toatl kredit yang telah diberikan oleh bank dengan total dana pihak ketiga yang dapat dihimpun oleh bank serta modal sendiri yang digunakan. Tujuan penting dari perhitungan LDR adalah untuk mengetahui serta menilai sampai seberapa jauh kinerja suatu perbankkan dalam menjalankan operasi atau kegiatan usaha.

Dari paparan diatas dapat diuraikan kembali bahwa LDR (loan to deposit ratio) adalah rasio perbandingan anatar total jumlah kredit dengan total dana pihak ketiga yang dihimpun oleh bank dan modal sendiri yang digunakan. Perbandingan tersebut untuk memperlihatkan besarnya penyaluran kredit dengan jumlah dana yang dihimpun perbankkan.

Berdasarkan peraturan Bank Indonesia No. 15/7/PBI/2013 standar LDR 78\% - 92\%. Jika ada rasio LDR dibawah 78\% maka dapat dikatakan bahwa bank tersebut tidak dapat menyalurkan kredit dengan baik dengan seluruh dana yang telah dihimpun, jika rasio LDR mencapai lebih dari 92\% maka total kredit yang disalurkan oleh bank telah melebihi dana yang telah dihimpun. Rasio LDR menurut Simorangkir (2004) dirumuskan sebagai berikut :

$$
\mathrm{LDR}=\frac{\text { Jumlah Kredit Yang Diberikan }}{\text { Total Dana Pihak Ketiga }} \quad \mathrm{X} 100 \%
$$

Rasio LDR menurut (Riyadi, 2006), dan Kasmir (2014) dapat dirumuskan sebagai berikut :

$\mathrm{LDR}=$

Total Kredit $100 \%$

Total dana pihak ketiga + modal

\subsection{Kualitas Aktiva Produktif (KAP)}

Menurut Dendawijaya (2003) Aktiva produktif atau Earning Assets adalah semua aktiva dalam rupiah dan valuta asing yang dimiliki bank dengan maksud untuk memperoleh penghasilan sesuai dengan fungsinya. Untuk mengetahui probabilitas kegagalan kredit yang akan disalurkan maka perlu diketahui kualitas aktiva produktifnya (KAP). Aktiva produktif yang diklasifikasikan adalah aktiva produktif yang mengandung potensi tidak memberikan penghasilan atau menimbulkan kerugian yang terdiri dari kredit dalam perhatian khusus, kredit kurang lancar, kredit diragukan, kredit macet.. Guna mengetahui probabilitas kegagalan kredit maka perlu diketahui kualitas aktiva produktif (KAP). KAP merupakan rasio antara aktiva produktif yang diklasifikasikan (APYD) terhadap total aktiva produktif. APYD terdiri dari kredit dalam perhatian khusus, kredit kurang lancar, kredit diragukan, dan kredit macet (Riyadi, 2006). Jadi berdasarkan paparan diatas dapat diuraikan kembali bahwa KAP (Kualitas Aktiva Produktif) merupakan rasio yang mengukur prosentase perbandingan antara aktiva produktif yang diklasifikasikan terhadap aktva produktif. Rasio KAP menurut (Riyadi, 2006) dapat dirumuskan sebagai berikut:

$$
\mathrm{KAP}=\frac{\text { Aktiva produktif yang diklasifikasikan }}{\text { Aktiva Produktif }} \times 100 \%
$$

\subsection{BOPO (Biaya Operasional dengan Pendapatan Operasional)}

Biaya operasional Bank yang terlalu tinggi atau sama dengan pendapatan operasional tidak akan mendatangkan keuntungan bagi Bank tersebut. Pendapatan Bank yang tinggi dengan biaya operasional yang rendah dapat menekan rasio BOPO sehingga Bank tersebut berada pada posisi sehat, yang artinya kencederungan untuk meminimalisir terjadinya kredit macet dapat diatasi (Adisaputra, 2012). Rasio BOPO sering disebut rasio efisiensi yang digunakan untuk mengukur kemampuan manajemen bank dalam mengendalikan biaya operasional terhadap pendapatan operasional. Efisiensi operasi dilakukan oleh bank dalam rangka untuk mengetahui apakah bank dalam operasinya yang berhubungan dengan usaha pokok bank, dilakukan dengan 
benar (sesuai dengan harapan pihak manajemen dan pemegang saham) serta digunakan untuk menunjukkan apakah bank telah menggunakan semua faktor produksinya dengan tepat guna dan berhasil guna (Mawardi, 2005).

BOPO merupakan rasio antara biaya operasi terhadap pendapatan operasi. Biaya operasi merupakan biaya yang dikeluarkan oleh bank dalam rangka menjalankan aktivitas usaha utamanya seperti biaya bunga, biaya pemasaran, biaya tenaga kerja dan biaya operasi lainnya. Pendapatan operasi merupakan pendapatan utama bank yaitu pendapatan yang diperoleh dari Penempatan dana dalam bentuk kredit dan pendapatan operasi lainnya. Semakin kecil rasio ini berarti semakin efisien biaya operasional yang dikeluarkan bank yang bersangkutan. Menurut Dendawijaya (2003) rasio biaya operasional digunakan untuk mengukur tingkat efisiensi dan kemampuan bank dalam melakukan kegiatan operasinya. Semakin rendah BOPO berarti semakin efisien bank tersebut dalam mengendalikan biaya opersionalnya. Mengingat kegiatan utama bank pada prinsipnya adalah bertindak sebagai perantara, yaitu menghimpun dan menyalurkan dana, maka biaya dan pendapatan operasional bank didominasi oleh biaya bunga dan pendapatan bunga (Dendawijaya, 2003). BOPO adalah rasio perbandingan antara Biaya Operasional dengan Pendapatan Operasional (Riyadi, 2006). Rasio BOPO disebut sebagai rasio efisiensi yang digunakan untuk mengukur kemampuan manajemen bank dalam mengendalikan biaya operasional terhadap pendapatan operasional dalam kegiatan operasionalnya. Besarnya rasio BOPO yang dapat ditolerir oleh perbankan di Indonesia adalah sebesar 93, 52\%.

Berdasarkan penjelasan diatas dapat diuraikan kembali bahwa BOPO merupakan rasio yang digunakan untuk mengukur perbandingan antara biaya terhadap pendapatan yang diterima. BOPO dapat dirumuskan sebagai berikut (Loen \& Ericson, 2007).

$$
\mathrm{BOPO}=\frac{\text { Biaya Operasional }}{\text { Pendapatan Operasional }} \times 100 \%
$$

\subsection{Pengaruh Variabel Independen terhadap Variabel Dependen \\ 2.6.1 Pengaruh CAR Terhadap NPL}

Capital Adequacy Ratio (CAR) adalah rasio yang memperlihatkan seberapa jauh seluruh aktiva bank yang mengandung risiko (kredit, penyertaan, surat berharga, tagihan pada bank lain) ikut dibiayai dari dana modal sendiri bank disamping memperoleh dana-dana dari sumber-sumber di luar bank, seperti dana dari masyarakat, pinjaman dan lain-lain (Dendawijaya, 2003). Dari pengertian tersebut berarti bahwa modal sendiri dari bank digunakan untuk membiayai aktiva yang mengandung risiko. Semakin tinggi modal yang dimiliki bank maka akan semakin mudah bagi bank untuk membiayai aktiva yang mengandung risiko. Begitu juga sebaliknya jika kredit yang tinggi tidak disertai dengan modal yang mencukupi maka akan berpotensi menimbulkan kredit bermasalah. Sehingga dapat disimpulkan semakin tinggi CAR maka akan semakin rendah risiko kredit yang dihadapi bank. Karena apabila kredit yang disalurkan maka risiko kredit pun akan meningkat.

Menurut Bank Indonesia (dalam Diyanti, 2012) menyatakan bahwa permodalan berpengaruh negatif terhadap kondisi bermasalah .Hal ini memberikan indikasi negatif pengaruh CAR terhadap NPL, sesuai dengan hasil penelitian yang telah dilakukan Hermawan Soebagio (2005) dan Diyanti (2012) yang menyatakan bahwa CAR berpengaruh negatif terhadap NPL. Berdasarkan uraian tersebut dapat dirumuskan sebagai berikut :

Hipotesis 1 : CAR berpengaruh negatif terhadap NPL

\subsubsection{Pengaruh LDR Terhadap NPL}

LDR adalah ratio antara seluruh jumlah kredit yang diberikan bank dibandingkan dengan dana yang diterima oleh bank. Banyaknya dana pihak ketiga yang dihimpun oleh sebuah bank, berbanding lurus dengan besarnya kredit yang dikeluarkan, artinya semakin 
banyak dana pihak ketiga maka semakin banyak pula kredit yang dikeluarkan (Adisaputra, 2012). Maka dapat diambil kesimpulan apabila rasio LDR meningkat maka kemampuan likuiditas akan menurun. Hal ini disebabkan oleh jumlah dana yang diperlukan untuk membiayai kredit semakin besar. Semakin tinggi LDR maka memberikan indikasi semakin rendahnya kemampuan likuiditas bank yang bersangkutan (Dendawijaya, 2003). Sesuai dengan hasil penelitian yang dilakukan B.M. Misra dan Sarat Dhal (2010) serta Iksan Adisaputra (2012) yang mengemukakan bahwa terdapat pengaruh positif antara LDR dengan NPL, maka dapat diambil hipotesis sebagai berikut :

Hipotesis 2 : LDR berpengaruh positif terhadap NPL

\subsubsection{Pengaruh KAP Terhadap NPL}

Rasio Kualitas Aktiva Produktif (KAP) merupakan ukuran kualitas aktiva produktif, dimana semakin besar rasio KAP maka kualitas aktiva produktif rendah atau sebaliknya semakin rendah rasio KAP maka kualitas aktiva produktif tinggi karena aktiva produktif dibandingkan dengan aktiva produktif yang diklasifikasikan. Pernyataan tersebut memberikan indikasi bahwa kualitas aktiva produktif (KAP) bepengaruh positif tehadap NPL. Maka dapat dirumuskan :

\section{Hipotesis 3 : KAP berpengaruh positif terhadap NPL}

\subsubsection{Pengaruh BOPO Terhadap NPL}

Menurut Dendawijaya (2003), rasio BOPO berpengaruh pada keadaan bermasalah. Semakin kecil rasio BOPO berarti semakin efisien biaya operasional yang dikeluarkan bank yang bersangkutan sehingga kemungkinan suatu bank dalam kondisi bermasalah semakin kecil (Soma, 2011). Sehingga dapat disimpulkan bahwa biaya operasional berpengaruh positif karena semakin kecil rasio BOPO maka kondisi bermasalah juga semakin kecil atau sebaliknya. Hal ini didukung dengan penelitian yang telah dilakukan Adisaputra (2012) yang menyatakan BOPO berpengaruh postif terhadap NPL. Sehingga dari uraian ini dapat dirumuskan sebagai berikut :

Hipotesis 4 : Biaya operasional (BOPO) berpengaruh positif terhadap NPL.

\section{Metode Penelitian}

Penelitian ini dilakukan pada Lembaga Perkreditan Desa (LPD) Desa Adat Pedawa yang beralamat di Dusun Desa, Desa Pedawa, Kecamatan Banjar, Kabupaten Buleleng, dalam penelitian menggunakan populasi dan sampel yaitu jumlah 36 Bulan atau 3 Tahun meggunakan teknik purpostve sampling, teknik pengumpulan menggunakan proses pengamatan pada data laporan keuangan yang didapatkan pada LPD Desa Adat Pedawa periode 2017-2019 yang dihitung rasio masing-masing variabel dan menggunakan Analisis Regresi Linier Berganda, Analisis Uji Asumsi Klasik, Analisis Uji F (F-Test) Analisis Determinasi dan Analisis Uji T (T-Test).

\section{Hasil Penelitian}

Rasio merupakan satu angka yang dibandingkan dengan angka lain sebagai suatu hubungan. Perhitungan rasio digunakan untuk mengetahui gambaran informasi mengenai posisi keuangan dan efektivitas kinerja perusahaan. Dalam penelitian ini rasio yang dihutung adalah rasio NPL dengan standar nilai rasio maksimul $5 \%$, rasio CAR dengan standar nilai rasio minimal $12 \%$, rasio LDR dengan standar nilai rasio maksimal 94,75\%, rasio KAP dengan standar nilai rasio maksimal 7,80 \%, dan rasio BOPO dengan standar nilai rasio 
maksimal 79,75\%.

Hasil perhitungan rasio yang berada pada lampiran 1 halaman satu, bahwa dapat dilihat rasio NPL selama tiga tahun dari 2017 sampai 2019 melebihi batas standar maksimum nilai rasio NPL, dengan kata lain pengelolaan NPL di LPD Desa Adat Pedawa masih belum efektivitas. Selanjutnya hasil perhitungan rasio CAR terlihat sudah melebihi dari nilai standar nilai rasio CAR, yang artinya pengelolaan CAR di LPD Desa Adat pedawa sudah cukup efektiv. Hasil rasio LDR dan BOPO tidak melebihi nilai standar rasio yang ditetapkan, yang artinya pengelolaan LDR dan BOPO dalam LPD Desa adat Pedawa Sudah efektiv. Dan untuk rasio KAP dapat dilihat hasilnya melebihi batas standar maksimal rasio KAP, hal ini berarti pengelolan KAP di dalam LPD Desa adat Pedawa masih belum efektif.

Hasil perhitungan analisis regresi dengan program SPSS terkait dengan variabel yang diteliti yaitu Efektivitas Pengelolaan NPL (Non Performing Loan) Di Lembaga Perkreditan Desa (LPD) Desa Adat Pedawa sebagai berikut :

$$
\begin{aligned}
& Y=a+B_{1} X_{1}+B_{2} X_{2}+B_{3} X_{3}+B_{4} X_{4}+e \\
& Y=78,0201,573 X_{1}+0,504 X_{2}+1,739 X_{3}+0,168 X_{4}+11,93
\end{aligned}
$$

Hasil uji normalitas dengan menggunakan One-Sample Kolmogorov-Smirnov Test menunjukkan bahwa nilai Asymp Sig. (2-Tailed) memiliki nilai sebesar 0,241 >0,05 sehingga dapat disimpulkan bahwa data yang digunakan sudah berdistribusi normal.

\begin{tabular}{|l|l|l|l|}
\multicolumn{4}{|c|}{ Tabel 1. Uji Multikolinearitas } \\
\hline Variabel & \multicolumn{2}{|l|}{$\begin{array}{l}\text { Collinearity } \\
\text { Statistics }\end{array}$} \\
\cline { 2 - 4 } & Tolerance & VIF \\
\hline $\begin{array}{l}\text { Capital Adequacy } \\
\text { Ratio }\end{array}$ & 0,259 & 3,859 \\
\hline $\begin{array}{l}\text { Loan to Deposit } \\
\text { Ratio }\end{array}$ & 0,218 & 4,578 \\
\hline $\begin{array}{l}\text { Kualitas Aktiva } \\
\text { Prdoduktif }\end{array}$ & 0,243 & 4,107 \\
\hline $\begin{array}{l}\text { Biaya Operasional } \\
\text { Terhadap } \\
\text { Pendapatan } \\
\text { Operasional }\end{array}$ & 0,610 & 1,640 \\
\hline
\end{tabular}

Sumber : Lampiran 4 Uji Multikolinearitas

Nilai tolerance untuk masing-masing variabel lebih dari 0,1 dan nilai VIP kurang dari 10.

Dengan demikian dapat disimpulkan semua variabe bebas tidak mengalami kasus multikolineritas.

Tabel 2 Uji Autokorelasi

\begin{tabular}{|l|l|l|}
\hline Durbin-Watson $(\mathrm{d})$ & $\begin{array}{l}\text { Nilai tabel Durbin-Watson } \\
(\mathrm{dU})\end{array}$ & 4-dU \\
\hline 1,835 & 1,654 & $4-1,654=2,346$ \\
\hline
\end{tabular}

Sumber : Lampiran 5 Uji Autokorelasi

Nilai Durbin-Watson $=1,835$, Nilai tabel Durbin-Watson $(\mathrm{dU})=1,654$, dan nilai 4-dU 
$=2,346$. Dari hasil tersebut terlihat bahwa nilai Durbin-Watson berada pada interval $\mathrm{dU}<\mathrm{d}<$ 4-Du. Oleh karena nilai tersebut berada pada interval $\mathrm{dU}<\mathrm{d}<4$-dU maka dapat disimpulkan bahwa data hasil penelitian yang diperoleh tidak ada autokorelasi positif ataupun negatif.

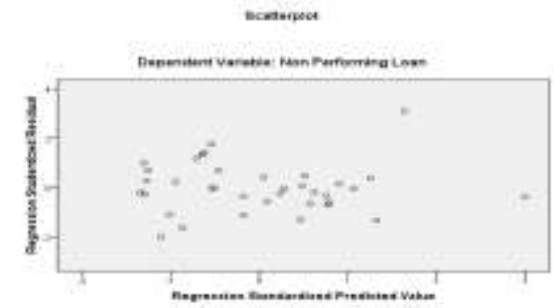

Gambar 1. Grafik Scatterplot

Sumber : Hasil Uji Asumsi Klasik

Hasil Grafik scatterplot yang disajikan di atas dapat diketahui bahwa, penyebaran titiktitik tersebar secara merata dibawah dan di atas angka nol. Sehingga dapat dikatakan bahwa dalam model regresi tidak terdapat masalah heterokedastisitas. Hasil perhitungan F-hitung > F-tabel, dengan nilai F-hitung sebesar 102,161 dan tingkat signifikan 0,00 ini menandakan bahwa Biaya Operasional Terhadap Pendapatan Operasional, Capital Adequacy Ratio, Kualitas Aktiva Prdoduktif, Loan to Deposit Ratio berpengaruh terhadap Non Performing Loan. Nilai koefisien korelasi $\mathrm{R}^{2}$ (R Square) sebesar 0,929 atau (92,9\%). Hal ini menunjukkan bahwa prosentase sumbangan pengaruh variabel bebasterhadap variabel terikat sebesar $92,9 \%$. Atau variasi variabel bebas yang digunakan dalam mampu menjelaskan sebesar $92,9 \%$ variasi variabel terikat. Sedangkan sisanya sebesar 7,1\% dipengaruhi atau dijelaskan oleh variabel lain yang tidak dimasukkan dalam model penelitian ini.

CAR (X1) terhadap NPL (Y) berpengaruh negatif, dapat dilihat dari pengujian parsial (uji-t) $=0,000$ lebih kecil dari 0,05. Hal ini berakibat pada penolakan terhadap H0 dan H1 yang diterima. Koefisien regresi variabel (X1) sebesar -1,573; artinya Koefisien bernilai negatif artinya terjadi hubungan negatif antara Capital Adequacy Ratio dengan Non-Performing Loan. (Hepotesis diterima). LDR (X2) berpengaruh secara positif dan signifikan terhadap NPL (Y) Nilai signifikansi untuk variabel Loan to Deposit Ratio $(\mathrm{X} 2)=0,000$ lebih kecil dari 0,05. Koefisien regresi variabel Loan to Deposit Ratio (X2) sebesar 0,504,artinya,Koefisien bernilai postif artinya terjadi hubungan positif antara Loan to Deposit Ratio dengan Non-Performing Loan, semakin baik Loan to Deposit Ratio maka semakin baik pula Non-Performing Loan. (Hepotesis diterima)

KAP (X3) berpengaruh positif dan signifikan terhadap NPL (Y), dengan nilai signifikansi untuk variabel Kualitas Aktiva Prdoduktif $(X 3)=0,000$ lebih kecil dari 0,05. Koefisien regresi variabel Kualitas Aktiva Prdoduktif (X3) sebesar 1,739; artinya Koefisien bernilai postif artinya terjadi hubungan positif antara Kualitas Aktiva Prdoduktif dengan NonPerforming Loan, semakin baik Kualitas Aktiva Prdoduktif maka semakin baik pula NonPerforming Loan. (Hipotesis diterima). BOPO (X4) berpengaruh positif dan signifikan terhadap NPL (Y) dengan Nilai signifikansi untuk variabel Biaya Operasional Terhadap Pendapatan Operasional $(\mathrm{X} 4)=0,036$ lebih kecil dari 0,05 dan Koefisien regresi variabel Biaya Operasional Terhadap Pendapatan Operasional (X4) sebesar 0,168; artinya Koefisien bernilai postif artinya terjadi hubungan positif antara Biaya Operasional Terhadap Pendapatan Operasional dengan Non-Performing Loan, semakin baik Biaya Operasional Terhadap 


\section{PEMBAHASAN}

1. Pengaruh CAR $\left(\mathrm{X}_{1}\right)$ terhadap NPL (Y) LPD Desa Adat Pedawa.

Hasil diatas maka dapat dipaparkan bahwa CAR $\left(\mathrm{X}_{1}\right)$ terhadap NPL $(\mathrm{Y})$ berpengaruh negatif, dapat dilihat dari pengujian parsial $(u j i-t)=0,000$ lebih kecil dari 0,05 . Hal ini berakibat pada penolakan terhadap $\mathrm{H} 0$ dan $\mathrm{H}_{1}$ yang diterima. Koefisien regresi variabel $\left(\mathrm{X}_{1}\right)$ sebesar 1,573; artinya jika variabel bebas lain nilainya tetap dan variabel Capital Adequacy Ratio mengalami kenaikan 1 satuan, maka Non-Performing Loanakan mengalami penurunan sebesar 1,573. Koefisien bernilai negatif artinya terjadi hubungan negatif antara Capital Adequacy Ratio dengan Non-Performing Loan. (Hepotesis diterima). Menurut Bank Indonesia (dalam Diyanti, 2012) menyatakan bahwa permodalan berpengaruh negatif terhadap kondisi bermasalah .Hal ini memberikan indikasi negatif pengaruh CAR terhadap NPL, sesuai dengan hasil penelitian yang telah dilakukan Hermawan (2005) dan (Soebagio, 2005), (Dianti \& Widyarti, 2012) dan (Makri et al., 2014). yang menyatakan bahwa CAR berpengaruh negatif terhadap NPL Hal ini memberikan indikasi negatif pengaruh CAR terhadap NPL.

\section{Pengaruh LDR $\left(\mathrm{X}_{2}\right)$ terhadap NPL $(\mathrm{Y})$ LPD Desa Adat Pedawa}

Hasil penelitian ini menunjukan bahwa LDR $\left(\mathrm{X}_{2}\right)$ berpengaruh secara positif dan signifikan terhadap NPL (Y) Nilai signifikansi untuk variabel Loan to Deposit Ratio $\left(\mathrm{X}_{2}\right)=$ 0,000 lebih kecil dari 0,05. Koefisien regresi variabel Loan to Deposit Ratio $\left(\mathrm{X}_{2}\right)$ sebesar 0,504; artinya jika variabel bebas lain nilainya tetap dan Loan to Deposit Ratio mengalami kenaikan 1 satuan, maka Non-Performing Loan akan mengalami peningkatan sebesar 0,504. Koefisien bernilai postif artinya terjadi hubungan positif antara Loan to Deposit Ratio dengan NonPerforming Loan, semakin baik Loan to Deposit Ratio maka semakin baik pula NonPerforming Loan. (Hepotesis diterima).Banyaknya dana pihak ketiga yang dihimpun oleh sebuah bank, berbanding lurus dengan besarnya kredit yang dikeluarkan, artinya semakin banyak dana pihak ketiga maka semakin banyak pula kredit yang dikeluarkan (Adisaputra, 2012). Semakin tinggi LDR maka memberikan indikasi semakin rendahnya kemampuan likuiditas bank yang bersangkutan. Hal ini didukung dengan penelitian yang dilakukan B.M. Misra dan Sarat Dhal (2010) dan Iksan Adisaputra (2012) (Dyanti \& Widyarti, 2012; Jayanti \& Haryanto, 2013; Akinlo \& Emmanuel, 2014). yang mengemukakan bahwa terdapat pengaruh positif antara LDR dengan NPL.

\section{Pengaruh KAP $\left(\mathrm{X}_{3}\right)$ terhadap NPL (Y) LPD Desa Adat Pedawa}

Hasil penelitan ini menunjukan bahwa KAP $\left(\mathrm{X}_{3}\right)$ berpengaruh positif dan signifikan terhadap NPL (Y), dengan nilai signifikansi untuk variabel Kualitas Aktiva Prdoduktif $\left(\mathrm{X}_{3}\right)=$ 0,000 lebih kecil dari 0,05. Koefisien regresi variabel Kualitas Aktiva Prdoduktif $\left(\mathrm{X}_{3}\right)$ sebesar 1,739; artinya jika variabel bebas lain nilainya tetap dan Kualitas Aktiva Prdoduktif mengalami kenaikan 1 satuan, maka Non-Performing Loan akan mengalami peningkatan sebesar 1,739. Koefisien bernilai postif artinya terjadi hubungan positif antara Kualitas Aktiva Prdoduktif dengan Non-Performing Loan, semakin baik Kualitas Aktiva Prdoduktif maka semakin baik pula Non-Performing Loan. (Hipotesis diterima). Banyaknya dana pihak ketiga yang dihimpun oleh sebuah bank, berbanding lurus dengan besarnya kredit yang dikeluarkan, artinya semakin banyak dana pihak ketiga maka semakin banyak pula kredit yang dikeluarkan (Adisaputra, 2012). Maka dapat diambil kesimpulan apabila rasio LDR meningkat maka kemampuan likuiditas akan menurun. Hal ini disebabkan oleh jumlah dana yang diperlukan untuk membiayai kredit semakin besar. Hal ini didukung dengan hasil penelitian yang dilakukan Iksan Adisaputra (2012), sSoebagio (2005) dan Jayanti dan Haryanto (2013) yang 
mengemukakan bahwa terdapat pengaruh positif antara LDR dengan NPL.

\section{4. $\quad$ Pengaruh BOPO $\left(\mathrm{X}_{4}\right)$ terhadap NPL $(\mathrm{Y})$ di LPD Desa Pedawa}

Hasil penelitin ini dapat menunjukan bahwa BOPO $\left(\mathrm{X}_{4}\right)$ berpengaruh positif dan signifikan terhadap NPL (Y) dengan Nilai signifikansi untuk variabel Biaya Operasional Terhadap Pendapatan Operasional $\left(\mathrm{X}_{4}\right)=0,036$ lebih kecil dari 0,05 dan Koefisien regresi variabel Biaya Operasional Terhadap Pendapatan Operasional $\left(\mathrm{X}_{4}\right)$ sebesar 0,168 ; artinya jika variabel bebas lain nilainya tetap dan Biaya Operasional Terhadap Pendapatan Operasional mengalami kenaikan 1 satuan, maka Non-Performing Loan akan mengalami peningkatan sebesar 0,168. Koefisien bernilai postif artinya terjadi hubungan positif antara Biaya Operasional Terhadap Pendapatan Operasional dengan Non-Performing Loan, semakin baik Biaya Operasional Terhadap Pendapatan Operasional maka semakin baik pula NonPerforming Loan. (Hipotesis diterima). Semakin kecil rasio BOPO berarti semakin efisien biaya operasional yang dikeluarkan bank yang bersangkutan sehingga kemungkinan suatu bank dalam kondisi bermasalah semakin kecil (Soma, 2011). Sehingga dapat disimpulkan bahwa biaya operasional berpengaruh positif karena semakin kecil rasio BOPO maka kondisi bermasalah juga semakin kecil. Hal ini didukung dengan penelitian yang telah dilakukan Iksan Adisaputra (2012) jayanti dan riyanto (2013) dan Hardoyo dan Rusdiyanti (2009) yang menyatakan BOPO berpengaruh postif terhadap NPL.

\section{SIMPULAN DAN SARAN}

Variabel Capital Adequacy Ratio (CAR) berpengaruh signifikan negatif terhadap NPL pada LPD Desa Adat Pedawa. Hal ini menunjukan bahwa menyatakan semakin meningkat Capital Adequacy Ratio, maka Non-Performing Loan akan mengalami penurunan. Variabel Loan to Deposit Ratio (LDR), Kualitas Aktiva Produktif (KAP) dan Biaya Operasional Pendapatan Operasional (BOPO) berpengaruh signifikan positif terhadap NPL (NonPerforming Loan) pada LPD Desa Adat Pedawa. Hal ini menunjukan bahwa semakin baik Loan to Deposit Ratio, Kualitas Aktiva Prdoduktif dan Biaya Operasional Pendapatan Operasional (BOPO) maka semakin baik pula Non-Performing Loan.

Dalam penelitian ini, untuk memaksimalkan NPL di LPD Desa Adat Pedawa, peneliti dapat memberikan saran kepada LPD Desa Adat Pedawa yaitu dalam melaksanakan kegiatan perusahaan harus memperhatikan faktor - faktor yang mempengaruhi NPL, diantaranya LDR (Loan to Deposit Ratio) yang merupakan rasio perbandingan antara total jumlah kredit dengan total dana pihak ketiga yang dihimpun oleh bank dan modal sendiri yang digunakan. Karena Semakin besar kredit yang disalurkan dibandingkan dengan simpanan masayarakat, membawa konsekuensi bahwa semakin besar resiko yang harus ditanggung.

Faktor yang harus diperhatikan selanjutnya adalah KAP (Kualitas Aktiva Produktif) yang merupakan rasio yang mengukur prosentase perbandingan antara aktiva produktif yang diklasifikasikan terhadap aktva produktif. Karena Jika APYD meningkat artinya kredit dalam perhatian kusus, kredit kurang lancar, kredit ditragukan, dan kredit macet juga meningkat. Dengan demikian, jika rasio KAP tinggi berati tingkat kredit macet atau bermasalah juga tinggi. Faktor yang harus diperhatikan juaga adalah BOPO yang merupakan rasio perbandingan antara Biaya Operasional dengan Pendapatan Operasional. Karena Semakin kecil rasio BOPO berati semakin efesien biaya operasional yang dikeluarkan sehingga LPD dalam kondisi bermasalah semakin kecil.

Peneliti berikutnya atau mahasiswa lain yang ingin meneliti tentang Efektivitas NPL 
dipenelitian selanjutnya agar mengembangkan penelitian ini lebih lanjut dan mempertimbangkan variabel lain yang belum diuji pada penelitian ini.

\section{Referensi}

Adisaputra, Ikhsan. 2012. Analisi Faktor-Faktor Yang Mempengaruhi Non Performing Loan Pada PT. Bank Mandiri (Persero) Tbk. Skripsi Pada Universitas Hasanudin Makasar.

Akinlo, O \& Emmanuel, M. (2014). Determinants of Non-Performing Loans in Nigeria. Accounting \& Taxation, 6(2), 21-28

Chikoko, L, Mutambanadzo, T \& Vhimisai, T. (2012). Insights on Non-Performing Loans: Evidence from Zimbabwean Commercial Banks in a Dollarised Environment (20092012). Journal of Emerging Trends in Economics and Management Sciences, 3(6), $882-886$

Dendawijaya, L. 2009. Manajemen Perbankan. Edisi Kedua. Jakarta: Ghalia Indonesia.

Dendawijaya, Lukman. (2003). Manajemen Perbankan, Edisi Kedua. Jakarta : Ghalia Indonesia

Diyanti, A \& Widyarti, E. T. (2012). Analisis Pengaruh Faktor Internal dan Eksternal terhadap terjadinya Non-Performing Loan (Studi Kasus pada Bank Umum Konvensional yang Menyediakan Layanan Kredit Pemilikan Rumah Periode 20082011). Diponegoro Journal of Management, 1 (4), 290-299.

Ismail. (2010). Analisis Pengaruh Car, Npl, Dan Ldr Terhadap Profitabilitas pada perushaan Perbankan. E-Jurnal Manajemen Universitas Udayana.

Jusmansyah, M \& Sriyanto, A. (2013). Analisis Pengaruh CAR, BOPO dan ROA terhadap Non Performance Loan. Jurnal Akuntansi dan Keuangan, 2(1), 46-65.

Kasmir. (2006). Manajemen perbankan. Jakarta: Raja Grafindo Persada

Makri, V., Tsagkanos, A \& Bellas, A. (2014). Determinants of Non-Performing Loans: The Case of Eurozone. Panoeconomicus, 61(2), 193-206.

Mawardi, Wisnu. (2005). Analisis Faktor-Faktor Yang Mempengaruhi Kinerja Keuangan Bank Umum Di Indonesia (Studi Kasus Pada Bank UmumDengan Total Asset Kurang Dari 1 Triliun). Jurnal Bisnis Strategi, 14(1), 83-93.

Riyadi, Selamet (2006). Banking assets And Liability Management. Jakarta: Fakultas Ekonomi Universitas Indonesia.

Riyadi, Selamet. (2004). Banking assets And Liability Management. Jakarta: Lembaga Penerbitan Fakultas Universitas Indonesia

Skarica, B. (2014). Determinants of Non-Performing Loans in Central and Eastern European countries. Financial Theory and Practice, 38(1), 37-59

Soebagio, H. (2005). Analisis Faktor-Faktor yang Mempengaruhi terjadinya Non-Performing Loan (NPL) pada Bank Umum Konvensional. Tesis Tidak Dipublikasi. Semarang: Program Pasca Sarjana Universitas Diponegoro Semarang.

Sudirman, I Wayan. 2013. Faktor-Faktor Penghambat Peningkatan Loan to Deposit Ratio (LDR) Perbankan di Propinsi Bali. Jurnal Ekonomi dan Bisnis Indonesia, 8(1), 21-36.

Vatansever, M \& Hepsen, A. (2015). Determining Impacts on Non-Performing Loan Ratio in 
IEMBA : Jurnal Ekonomi Pembangunan, Manajemen dan Bisnis, Akuntansi Volume 2 Nomor 2 ( Juni 2021 ) / e-journal.upr.ac.id

Turkey. Journal of Applied Finance and Banking, 5(1), 1-11.

Wardoyo, P \& Rusdiyanti, E. (2009). Faktor-Faktor yang mempengaruhi Non Performing Loan Bank Perkreditan Rakyat di Eks Karesidenan Semarang. Jurnal Dinamika Sosbud, 11 (2), 127-139.

Yulianto, A. A. (2006). Dasar-Dasar Manajemen Keuangan. Jakarta: Penerbit Salemba Empat. 